\title{
PENINGKATAN KARAKTER KEBERANIAN ANAK MELALUI BAHASA IBU DI TK AISYIYAH BUSTANUL ATHFAL SUNGAI PINANG OGAN ILIR
}

\author{
Dwi Putriyanti, Syafdaningsih, Sri Sumarni \\ Program Studi PG-PAUD, Fakultas Keguruan dan Ilmu Pendidikan Universitas \\ Sriwijaya \\ e-mail:dwiputriyanti8@gmail.com
}

\begin{abstract}
Abstrak
Penelitian tindakan kelas berjudul "Peningkatkan Karakter Keberania Anak Melalui Bahasa Ibu di TK Aisyiyah Bustanul Athfal Sungai Pinang Ogan Ilir”. Mempunyai tujuan untuk meningkatkan karakter keberania anak melalui bahasa ibu di tk aisyiyah bustanul athfal sungai pinang pada semester genap tahun ajaran 2017/2018 dengan jumlah 15 orang anak. Penelitian ini dilakukan 2 siklus, masing-masing siklus terdiri dari 3 pertemuan. Setiap pertemuan dilakukan 4 tahapan yaitu tahan pelaksanaan, perencanaan, pengamatan dan refleksi. Data diambi dengancara tes perbuatan dengan menggunakan lembar observasi. Setiap pertemuan dilakukan penelitian dengan tes perbuatan dari 3 pertemuan diambi rata-rata nilai tes perbuatan yang merupakan nilai tes pada siklus 1 . Jika nilai tes perbuatan tidak memenuhi keriteria yang ditetapkan maka dilanjutkan pada siklus ke 2 yang akan memperbaiki perlakuan berdasarkan refleksi pada siklus I. Hasil analisis data, di peroleh terjadi peningkatan dari pra siklus, siklus 1 ke siklus 2. Secara berturut-turut nilai anak yang mendapat kategoriminimal BSH adalah : 6 orang atau $40 \%$ pada pra siklus, meningkat menjadi 10 orang atau $69 \%$ pada siklus I dan pada siklus II meningkat menjadi 13 orang atau 87\%. Hasil penelitian menunjukkan bahwa dengan menggunakan bahasa ibu dapat meningkatkan karakter keberanian pada anak kelompok B Aisyiyah Bustanul Athfal Sungai Pinang.
\end{abstract}

Kata Kunci : karakter, keberanian, anak usia dini

\begin{abstract}
A classroom action research entitled "Improving Character of Childhood Trust through Mother Language in Aisyiyah Kindergarten Bustanul Athfal Sungai Pinang Ogan Ilir". It aims to improve the character of children's survival through mother tongue in tk aisyiyah bustanul athfal pinang river in the even semester of academic year 2017/2018 with the number of 15 children. This research is done 2 cycle, each cycle consist of 3 meeting. Each meeting is held in 4 stages: endurance, planning, observation and reflection. Data is taken by means of action tests using observation sheets. Each meeting is conducted by research with the action test of 3 meetings on average of the value of the action test which is the test value in cycle 1. If the value of the action test does not meet the prescribed keriteria then proceed to cycle 2 which will improve the treatment based on reflection on cycle I. The results of the data analysis, obtained from the increase of pre cycle, cycle 1 to cycle 2. In a row the value of children who got categoriminimal BSH is: 6 people or $40 \%$ in pre cycle, increased to 10 people or $69 \%$ in cycle I and in the second cycle increased to 13 people or $87 \%$. The results showed that using the mother tongue can increase the character of courage in children group Aisyiyah Bustanul Athfal Sungai Pinang.
\end{abstract}

Keywords: character, courage, early childhood 


\section{PENDAHULUAN}

Salah satu upaya dalam mengingkatkan sumber daya manusia yang berkualitas adalah melalui pendidikan. Pendidikan merupakan usaha sadar yang telah terencana dalam mewujudkan suasana proses belajar dalam mengembangkan seluruh potensi yang meliputi pengendalian diri, kepribadian, kecerdasan, akhlak mulia, serta keterampilan yang dilakukan seumur hidup. Usia dini merupakan usia yang sangat penting dalam pengembangan intelegensi seorang anak. Menurut Permendikbud 146 tahun 2014 pendidikan anak usia dini adalah suatu upaya pembinaan kepada anak 0-6 tahun yang dilakukan melalui pemberian rangsangan pendidikan untuk membantu pertumbuhan dan perkembangan jasmani dan rohani agar anak memiliki kesiapan dalam memasuki pendidikan lebih lanjut.

Pendidikan karakter harus di tanamkan sejak dini untuk dapat membentuk manuasia yang berkarakter. Mulyasa dalam Wiyani (2017) mengungkapkan bahwa pendidikan karakter akan sangat tepat jika diimplementasikan sejak dini, yaitu sejak anak belajar di lembaga PAUD seperti Taman Kanak-kanak (TK) atau Raudhatul Athfal (RA). Namun sungguh disayangkan, implementasi pendidikan karakter di TK maupun RA masih belum optimal. Penyebabnya adalah karena praktik manajemen di TK maupun RA masih dilakukan asal-asalan dan belum berpihak sepenuhnya pada implementasi pendidikan karakter. Sebagai seorang guru harus memiliki berbagai strategi-strategi yang kreatif untuk dapat menanamkan karakter sejak dini, usia dini merupakan usia emas (golden age), terjadi sekali selama kehidupan manusia, masa ini merupakan masa yang tepat untuk mengembangkan berbagai pontensi yang di miliki oleh anak salah satunya yaitu penanaman karakter keberanian.
Pendidikan karakter sangat penting diajarkan ke peserta didik, menurut Ningsih (2017) Pendidikan karakter adalah proses pemberian tuntunan kepada peserta didik untuk menjadi manusia seutuhnya yang berkarakter dalam dimensi hati, pikir, raga, rasa, dan karsa. Salah satu kemampuan yang di harapkan berkembang pada diri anak yaitu perilaku positif yang di tanamkan sejak dini salah satunya adalah keberanian untuk melakukan segala sesuatu yang berkaitan dalam proses pembelajaran, seperti berani mencoba sesuatu, berani tampil didepan kelas dan berani untuk berbicara di depan kelas.Menggunakan bahasa pertama atau sering di sebut bahasa ibu salah satu strategi yang sangat baik untuk mendukung aktivitas anak dalam proses pembelajaran, penggunaan bahasa ibu sangat efektif di gunakan dalam proses pembelajaran,perolehan bahasa anak menjadi dua macam, yaitu bahasa ibu (bahasa pertama) dan bahasa kedua (ketiga dan seterusnya).

Berdasarkan hasil observasi pada tanggal 25 Agustus sampai 25 September 2017di Taman Kanak-Kanak Aisyiyah Bustanul Athfal Sungai Pinang. pada anak usia dini jumlah siswa 15 orang anak. Diantaranya 7 anak laki-laki dan 8 anak perempuan. Pada anak usia dinikarakter keberanian yang dimiliki anak masih rendah. Hasil observasi menunjukan 3 (20\%) dari 15 orang anak memiliki keberanian yang baik sedangkan 7 (47\%) orang anak yang memiliki tingkat keberanian masih rendah. Hal ini terlihat dari kegiatan yang diberikan oleh guru pada saat melakukan pembelajaran mengalami beberapa kendala, yaitu bahasa yang di gunakan menjadi kendala utama.

Beberapa anak kurang memahami dan susah untuk menggunakan bahasa indonesia saat proses pembelajaran berlangsung sehingga anak kurang termotivasi untuk melakukan berbagai kegiatan dikarenakan kurangnya 
kepercayaan diri pada anakdengan penggunakan bahasa Indonesia yang belum di pahamimembuat anak kesulitan untuk berinteraksi, bermain, tampil di depan kelas serta melakukan aktivitas lainnya, saat menggunakan bahasa Indonesia anak sering kali menggunakan bahasa campuran yaitu bahasa Indonesia dan bahasa ibu.Kurangnya motivasi dari anak, guru tetap berusaha untuk melakukan pembelajaran sebagai salah satu penanaman karakter keberanian anak. Pendidikan karakter keberanian dengan menggunkan bahasa ibu dapat memudahkan guru dalam meningkatkan keberanian pada anak untukmelakukan berbagai kegiatan dalam proses pembelajaran selama berada di sekolah dengan menggunakan bahasa ibu.

Penelitian yang berjudul

Pemerolehan Bahasa Pada Anak (Kajian Psikolinguistik) oleh Arsanti, Meilan Jurnal PBSI (Vol. 3 No 2 tahun 2014) menyatakan bahwa pemerolehan bahasa pertama di awali dari anak-anak ketika belajar berbicara, proses yang berlangsung di dalam otak seorang anak ketika ia memperoleh bahasa pertamanya atau bahsa ibu. Pengajaran merupakan metode yang diupayakan agar anak terbentuk karakternya sesuai dengan potensinya masing-masing.Perlu disadari bahwa setiap anak didik memiliki karakter yang berbeda-beda.Penggunkan bahasa ibu dapat mendukung dan mendorong anak untuk dapat menanamkan karakter keberania anak.

Berdasarkan pada uraian tersebut peneliti memilih judul "Meningkatkan Karakter Keberania Anak Melalui Bahasa Ibu di TK Aisyiyah Bustanul Athfal Sungai Pinang Ogan Ilir”.

\section{METODE}

Metode penelitian ini menggunakan metode penelitian tindakan kelas sesuai dengan tujuan penelitian untuk meningkatkan kemampuan motorik halus anak melalui Busy Book. Jenis penelitian yang digunakan pada penelitian ini adalah penelitian tindakan kelas (classroom actionresearch) dengan menggunakan metode penelitian tindakan kelas (PTK) model Kemmis dan Taggart. Menurut Jaedun dalam Hanifah (2014:5)

Kegiatan Penelitian ini dilaksanakan di TK Telkom Baturaja Kelurahan Sukaraya Kecamatan Baturaja Timur Kab. Ogan Komering Ulu Sumatera Selatan pada semester genap 2017/2018.

Subjek dalam penelitian ini adalah anak TK Telkom Baturaja pada semester genap tahun ajaran 2017/2018. Jumlah anak di TK Telkom Baturaja berjumlah 12 anak, anak laki-laki 5 orang dan anak perempuan 7 orang.

Prosedur penelitian yang dilakukan denagn merujuk pada model Kemmis dan Taggart menurut Rochiati dalam Afandi, dkk (2017: 207-208) dilakukan melalui 4 tahapan, yaitu perencanaan (planning), tindakan (acting), observasi (observing) dan refleksi (reflecting).

Setiap penelitian selalu menggunakan alatpengumpulan data yang disusun dan disesuaikan dengan tujuan penelitian. Metodepengumpulan data yang peneliti gunakanadalah observasi. Metode observasi adalah metode pengumpulan data penelitian dengan melalui pengamatan terhadap objek yang di teliti (Dimyanti, 2015:92)

Data yang diperoleh selama penelitian berlangsung dianalisis baik secara kuantitatif maupun kualitatif untuk memperoleh hasil yang maksimal terhadap penelitian tindakan kelas yang dilakukan. Data digunakan sebagai bahan untuk menentukan tindakkan berikutnya. Keseluruhan data digunakan untuk mengambil kesimpulan dari tindakan yang dilakukan. Hasil analisis ini akan dimasukkan ke dalam laporan penelitian data yang diperoleh selama proses pembelajaran diolah dengan teknik persentase. Dari hasil tersebut maka penulis akan melihat pembelajaran seperti apa lagi yang akan diberikan sehingga kemampuan motoric 
halus anak meningkat sehingga diperoleh $75 \%$ anak yang mendapat nilai minimal berkembang sesuai harapan.

Teknik Analisis data observasi digunakan untuk melihat bagaimana pengembangan keterampilan berbicara anak dan proses kegiatan guru dalam belajar mengajar. Adapunindikator yang digunakan ada 4 indikator, yaitu gerakan jari jemari, gerakan pergelangan tangan, gerakan kedua tangan, koordinasi mata dan tangan. Kriteria penilaian yang digunakan Menurut Ditjen Mandas Diknas 2010 dikutip Dimyati (2014:103) yaitu dengan 4 kategorisasi: Belum Berkembang (BB), Mulai Berkembang (MB), Berkembang Sesuai Harapan (BSH), dan Berkembang Sangat Baik (BSB). Rentang skor yang digunakan dalam penelitian ini adalah sebagai berikut: Range $=$ skor tertinggi - skor terendah $=100-25$

$=75$

Karena banyak kategori kemampuan motorik halus ada 4 kategori, maka:

Rentang nilai $=$ Jadi intervalnya, yaitu:

25 sampai dengan 43

44 sampai dengan 62

63 sampai dengan 81

82 sampai dengan 100

Sehingga skor kemampuan motorik halus melalui media busy book sebagai berikut:

Tabel 1. Interval

\begin{tabular}{ll}
\hline Kriteria & Interval \\
\hline BB & $25-43$ \\
MB & $44-62$ \\
BSH & $63-81$ \\
BSB & $82-100$ \\
\hline
\end{tabular}

\section{HASIL DAN PEMBAHASAN}

Penelitian tindakan kelas (PTK) ini dilaksanakan dengan dua siklus. Peneliti mengumpulkan data dan mempresentasekan kemampuan anak pada keriteria yang sesuai dengan rapot anak pada semester sebelumnya. Hasil yang diperoleh yaitu sebanyak 47\% anak belum berkembang, 13 \% mulai berkembang, 20\% berkembang sesuai harapan dan 20\% anak berada pada keriteria berkembang sangat baik. Data hasil rapot anak dapat dilihat pada lampiran hal.

Pembelajaran yang diterapkan guru sangat penting dalam proses pembelajaran yang ada didalam kelas, karena sebagai dasar keterampilan dalam mengelola kelas dan menciptakan suasana belajar yang menyenangkan bagi anak salah satu dengan cara bermain sambil belajar. Selain itu penggunaan bahasa yang digunakan saat proses belajar haruslah menggunakan bahasa pertama yaitu bahasa ibu yang mudah di mengerti dan di pahami anak serta guru mencari strategi belajar semenarik mungkin agar anak berani dan lebih bersemangat dalam mengikuti kegiatan pembelajaran. Pembelajaran dirancang sedemikian rupa dan disesuaikan dengan tujuan pembelajaran agar terjadi belajar melalui bermain sehingga anak bisa mengikuti proses pembelajaran tanpa beban dan berani.

Pertemuan pertama dilakukan pada Tanggal 9 April 2018 dengan rencana peneliti membagi tiga kelompok untuk lakilaki terdiri dari dua kelompok ada yang tiga dan ada yang empar orang anak laki-laki dalam setiap kelompok, dan untuk anak perempuan terdiri dari enam orang anak. Peneliti menggunakan lembar observasi sebaga alat untuk melakukan penilaian pada anak, dengan menggunakan berbagai macam kendaraan darat sebagai media ajar untuk tanya jawab dengan anak, anak dimintak oleh guru untuk memperhatikan ganbar yang telah di bagikan oleh guru, setelah anak memperhatikan gambar, guru akan berkomunikasi pada setiap kelompok secara bergantian dan di sana anak akan berdiskusi dan melakukan tanya jawab antara guru dan murid, guru akan mengajukan pertanyaan sederhana seputar tentang gambar yang di pegang anak, anak akan menjawab pertanyaan yang di ajukan oleh guru secara 
sederhana. Setiap anak memegang gambar yang berbeda-beda dan akan menyampaikan/bercerita tentang gambar apa yang di pegang oleh anak, dan akan di tanyatanya oleh guru. Tema yang digunakan pada siklus I pertemuan I ini adalah kendaraan sub temanya yaitu kendaraan darat (mobil, bus, becak, sepeda, kereta api, motor).

Pertemuan kedua pada Tanggal 10 April 2018 peneliti merencanakan tindakan dengan cara guru menggunakan bahasa ibu agar anak mengerti apa yang cerita yang di sampaikan oleh guru dan anak memahami pertanyaan yang ditanyaka oleh guru, mendengar cerita dan pertanyaan dari guru dan guru pembimbing lain bertugas untuk menertifkan anak agar tidak ribut di kelasa, memberikan motivasi pada anak agar mengikuti pelajaran dengan baik.

Pertemuan keiga pada Tanggal 11 April 2018 peneliti merencanakan tindakan dengan cara bercerita didepan kelas dengan menggunakan gambar wayang, anak maju kedepan dan menceritakan cerita secara sederhana.

Hasil akhir setelah dilakukan tindakan pada siklus 1, menampilkan hasil akhir setelah dilakukan tindakan pada siklus 1 , diketahui bahwa ada 4 (27\%) anak dalam kriteria berkembang sangat baik, Selanjutnya ditemukan 6 (40\%) anak dalam kriteria berkembang sesuai harapan (BSH), dan 2 anak (13\%) anak dalam kriteria mulai berkembang (MB), kemudian untuk kriteria belum berkembang (BB) masih ada 3 anak (20\%). maka peneliti perlu mengadakan siklus selanjutnya yaitu siklus II.

Sebelum melanjutkan ke siklus II peneliti dan guru merefleksi diriapa yang akan dilakukan agar karakter keberanian pada anak kelompok B meningkat. Berdasarkan kelemahan pada siklus 1 pertemuan III peneliti merencanakan tindakan dalam melakukan kegiatan yaitu anak maju kedepan dan bercerita menggunakan bahasa ibu menggunakan gambar wayang-wayangan, guru memberikan motivasi sehingga anak tidak ribut dan pada pembelajaran bercerita menggunakan bahasa ibu dan guru memanggil nama anak satu persatu untuk melakukan kegiatan sehingga anak tidak ribut dan pada pembelajaran.

Pertemuan pertama sikus dua pada Tanggal 13 April 2018 peneliti merencanakan tindakan dalam kontek bermain menggunakan gambar wayang yaitu anak maju kedepan dan bercerita menggunakan bahasa ibu menggunakan gambar wayang-wayangan.

Pertemuan kedua pada Tanggal 16 April 2018 peneliti merencanakan tindakan dalam bermain membuat gerakan tentang kota palembang bersama dengan guru dan teman kelompok, memberikan penghargaan berupa reward di akhir pembelajaran dan menggunakan gerkangerakan yang membuat anak lebih tertarik untuk mengikuti kegiatan pembelajaran.

Pertemuan ketiga pada Tanggal 16 April 2018 peneliti merencanakan tindakan dengan cara menjawab pertanyaan dengan tepat sesuai dengan cerita menggunakan bahasa ibu.

Pada pertemuan ketiga ini untuk hasi pengamatan peneliti dan kolaborator adalah secara keseluruhan terjadi peningkatan dari pra-siklus, siklus I, hingga siklus II.

Pada siklus II menunjukkan bahwa ada 7 (67\%) dan termasuk dalam kategori berkembang sangat baik (BSB). Anak yang mendapat nilai 63-81 ada 6 anak (40\%) yang termasuk dalam kategori berkembang sesuai harapan (BSH). Anak yang mendapat nilai 44-62 ada 1 anak (7\%) dalam kategori (MB). Anak yang mendapat nilai 25-43 ada 1 anak (7\%) dalam kategori (BB) Sehingga pada siklus II diperolehlah 7 anak dengan persentase sebanyak $67 \%$ pada kriteria minimal berkembang sesuai harapan. 
Tabel 2. Hasil Rekapitulasi Keseluruhan karakter keberanian anak pada Prasiklus, Siklus I dan Siklus II

\section{Rekapitulasi Hasil Keseluruhan}

Prasiklus $\quad$ Siklus I $\quad$ Siklus II

$40 \% \quad 67 \% \quad 87 \%$

Tabel 2 di atas terlihat adanya peningkatan pada hasil dari Siklus I lebih tinggi 67\% dari Pra siklus 40\%, dan Hasil Siklus II lebih tinggi 87\% dari Siklus I. Untuk lebih jelas dapat dilihat pada Gambar.

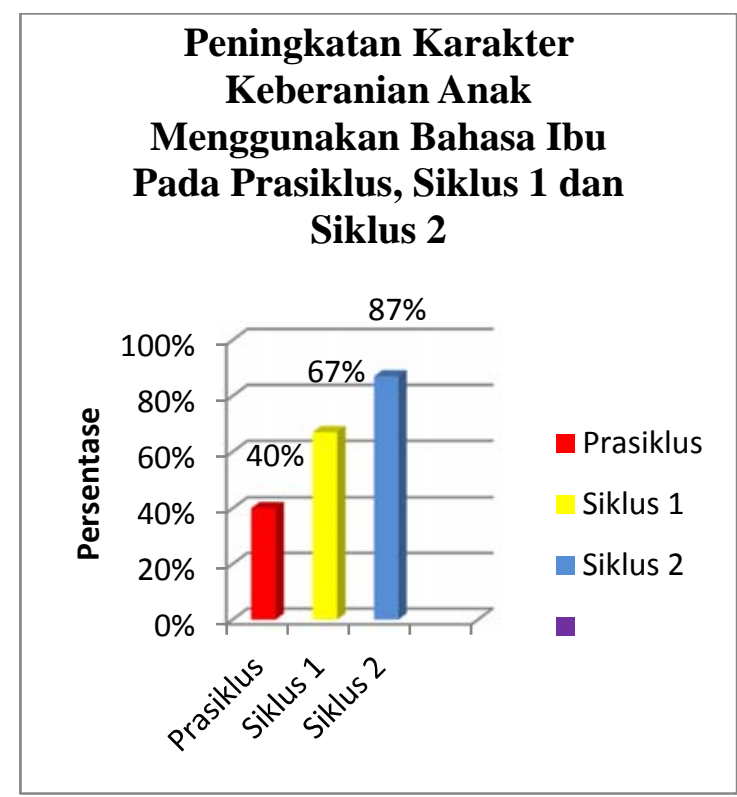

\section{Gambar 1. Diagram Batang Hasil Rekapitulasi Observasi Terhadap Karakter Keberanian Anak Menggunakan Bahasa Ibu Pada Prasiklus, Siklus 1 dan Siklus 2}

Gambar 1 diagram batang di atas, terlihat adanya peningkatan hasil rekapitulasi pada prasiklus, siklus I dan siklus II, peningkatannya yaitu dari pra siklus sebanyak 6 anak (40\%), karena anak mampu membawakan cerita di depan kelas menggunakan bahasa ibu dengan lancar sebanyak 9 dan 7 kata. Anak mampu bercerita menggunakan bahasa ibu diikuti dengan gerakan tangan anak secara lancar, anak mampu bercerita menggunakan bahasa ibu dengan lancar diikuti gerakan tangan anak yang masih kaku. Anak menjawab dengan tepat sesuai dengan cerita menggunakan bahasa ibu, dan anak mampu menjawab pertanyaan dari guru dengan diberikan pancingan terlebih dahulu menggunakan bahasa ibu. Begitu juga pada siklus I lebih meningkat dari pada pra siklus sebanyak 10 anak (69\%). Pada siklus II lebih tinggi dari siklus I sebanyak 13 anak (87\%).

\section{KESIMPULAN}

Berdasarkan hasil penelitian dan pembahasan yang telah diuraikan, dapat disimpulkan bahwa melalui bahaa ibu dapat meningkatkan karakter keberanian. Hal ini terbukti terjadi peningkatan dari pra siklus, siklus 1 ke siklus 2. Siklus 1 lebih tinggi dari pra siklus dan siklus 2 lebih tinggi dari siklus 1 Secara berturut-turut nilai anak yang mendapat kategori minimal BSH adalah : 10 orang atau $40 \%$ pada pra siklus, meningkat menjadi 15 orang atau 60\% pada siklus I dan pada siklus II meningkat menjadi 13 orang atau $87 \%$. Hal ini dapat dilihat juga pada siklus 1 indikator yang dominan muncul adalah melakukan sesuatu tanpa merisaukan kesulitan dan dengan rasa percaya diri yang sangat besar. Pada siklus 2 indikator yang dominan muncul adalah menyebutkan, mengungkapkan pendapat dan mempertahankannya, melakukan sesuatu tanpa merisaukan kesulitan dengan rasa percaya diri yang sangat besar. Sedangkan indikator yang kurang ialah mengungkapkan pendapat dan mempertahankannya. Jadi terjadi peningkatan karakter keberanian anak melalui bahasa ibu di TK Aisyiyah Bustanul Athfal Sungai Pinang Ogan Ilir”.

Berdasarkan penelitian yang telah dilakukan, penelitian berikutnya disarankan lebih dioptimalkan dalam penanaman karakter keberanian pada anak usia dini. Bagi sekolah dalam rangka perbaikan 
pembelajaran dan upaya meningkatkan karakter keberanian dalam proses pembelajaran, menggunakan bahasa ibu agar anak merasa berani ketika menjawab pertanyaan, bertanya, berkomunikasi sesama teman maupun dengan guru sehingga anak merasa percaya diri. Namun sesekali guru juga dapat menggunakan bahasa Indonesia untuk mengenalkan bahasa kedua anak, Diharapkan dapat menerapkan pembelajaran yang menyenangkan yang dapat membantu menstimulasi dan melatih anak dalam meningkatkan karakter keberanian anak, dan Bagi peneliti selanjutnya, diharapkan agar menggunakan permaiana, media dan alat peraga yang semenarik mungkin dan lebih bervariasi pada saat melakukan pertemuanpertemuan selanjutnya dengan menggunakan bahasa bahasa pertama yaitu bahasa ibu agar hasil penelitian yang diperoleh lebih baik dan memberikan kontribusi yang lebih tinggi dalam peningkatan karakter kebernian anak kelompok B.

\section{DAFTAR PUSTAKA}

Arsanti, M. (2014) Pemerolehan Bahasa Pada Anak (Kajian Psikolinguistik). Jurnal PBSI. 3(2): 24-47.

Afandi, Anjar Afif. Mardji.Wibawanto, Slamet. (2017) Pembelajaran Berbantu Komputer Pada Mata Pelajaran Sensor dan Aktuator Untuk
Meningkatkan Pengetahuan dan Keterampilan Siswa Smk Kelas Xi Teknik Elektronika Industri. Jurnal Pendidikan.2.(2): 206-211.

Dimyati, J. (2014) Metode Penelitian Pendidikan \& Aplikasinya Pada Pendidikan Anak Usia Dini. Jakarta: kencana.

Hanifah, Nurdina. (2014) Memahami Penelitian Tindakan Kelas. Bandung: UPI PRESS

Ningsih, Tutuk (2017) Pendidikan Multikultural Dalam Membentuk Karakter Bangsa Melalui Pembelajaran Ips Di Sekolah Confucius Terpadu Sd Mulia Bakti Purwokerto Kabupaten Banyumas. Jurnal Insania. 22(1): 366-377

Permendikbud. (2014).Nomor 146 Tahun 2014 Tentang Kurikulum 2013 Pendidikan Anak Usia Dini Dengan Rahmat Tuhan Yang Maha Esa Menteri Pendidikan Dan Kebudayaan Republik Indonesia.

Wiyani, N. A. (2017). Perencanaan Strategik Pembentukan Karakter Anak Usia Dini di TK Islam Al-Irsyad Purwokerto. Jurnal Pendidikan Anak. 3.(2): 105-118. 